Article

\title{
Retention of Silica Nanoparticles in a Lab-Scale Membrane Bioreactor: Implications for Process Performance and Membrane Fouling
}

\author{
Mark Larracas Sibag ${ }^{1}$, Soo Mi Lee ${ }^{1}$, Hee Jun Kim ${ }^{2}$ and Jinwoo Cho ${ }^{1, *}$ \\ 1 Department of Environment and Energy, Sejong University, 98 Gunja-dong, Gwangjin-gu, Seoul 143-747, \\ Korea; sibagmark@gmail.com (M.L.S.); lee4046@naver.com (S.M.L.) \\ 2 JIU Corporation, Yangcheon-ro, Gangseo-gu, Seoul 157-801, Korea; hjkim@jiuene.com \\ * Correspondence: jinwoocho@sejong.edu; Tel.: +82-2-3408-3970
}

Academic Editors: Stephen Gray and Hideto Matsuyama

Received: 9 May 2016; Accepted: 27 June 2016; Published: 4 July 2016

\begin{abstract}
In conventional activated sludge (CAS) involving aerobic biological processes, the retention of silica nanoparticles $\left(\mathrm{SiO}_{2} \mathrm{NPs}\right)$ has no detrimental effect on chemical oxygen demand (COD) and ammonia nitrogen $\left(\mathrm{NH}_{3}-\mathrm{N}\right)$ removal. However, for the membrane bioreactor (MBR) system, which is also based on the activated sludge process in addition to the membrane separation process, it has implications not only on the process performance but also on membrane fouling. To investigate these two implications in lab-scale experiments, we continuously operated a control MBR and two experimental MBRs, in which the $28 \mathrm{~nm} \mathrm{SiO} 2 \mathrm{NPs}$ and $144 \mathrm{~nm} \mathrm{SiO} \mathrm{NPs}_{2}$ were added separately to the influent at a final concentration of $100 \mathrm{mg} / \mathrm{L}$. Although the retention of $\mathrm{SiO}_{2} \mathrm{NPs}$ in the MBR, as confirmed by dynamic light scattering (DLS) analysis, did not compromise the COD and $\mathrm{NH}_{3}-\mathrm{N}$ removal, it resulted in substantial increases in the transmembrane pressure (TMP) suggesting the onset of membrane fouling. Analyses by batch-dead end filtration revealed the same fouling trend as observed during the continuous MBR experiments; membrane fouling is aggravated in the presence of $\mathrm{SiO}_{2}$ NPs. This was evident from permeate flux decline of between $30 \%$ and $74 \%$ at very low TMP $(5 \mathrm{kPa})$ and the further increases in the total resistance.
\end{abstract}

Keywords: silica nanoparticles; membrane bioreactor; membrane fouling; activated sludge respiration inhibition

\section{Introduction}

The presence of $\mathrm{SiO}_{2}$ NPs in wastewater discharged from domestic and industrial sources raises two concerns for the biological wastewater treatment systems. One is their substantial stability in wastewater [1] that leads to the release of some of them into the effluent stream [2]. Another one is the potential impact of their consequent retention in activated sludge [3,4], which is the core of biological wastewater treatment processes.

Although the presence of $\mathrm{SiO}_{2} \mathrm{NPs}$ in wastewater recently has been considered in operational strategies [5-7] and performance evaluation [8] for biological wastewater treatment systems, many of the studies have focused on CAS systems. In a CAS, the presence of $\mathrm{SiO}_{2} \mathrm{NPs}$ has no detrimental effect on the aerobic removal of $\mathrm{COD}$ [2] and $\mathrm{NH}_{3}-\mathrm{N}$ [8]. Hence, the greater concern for developing strategies is to improve their aggregation with, incorporation into and settling along with activated sludge $[1,5]$ instead.

Additional efforts are also needed to extend this research to membrane bioreactor (MBR) systems, which are also based on the activated sludge process in addition to a membrane separation process that allows MBR operation at higher mixed liquor suspended solids (MLSS) and longer sludge retention 
time (SRT) [9]. Thus, one may expect that the biological response to $\mathrm{SiO}_{2}$ in an $\mathrm{MBR}$ is similar to that observed in a CAS considering that the biological processes occurring in both systems are governed by activated sludge process. To demonstrate this, we performed continuous lab-scale MBR experiments under a constant flux and evaluated the response of activated sludge to $\mathrm{SiO}_{2} \mathrm{NPs}$ based on the activated sludge respiration inhibition test and measurement of the removal efficiency of COD and $\mathrm{NH}_{3}-\mathrm{N}$. As the particle size may influence $\mathrm{SiO}_{2} \mathrm{NPs}^{\prime}$ colloidal stability in wastewater [1-10] and thus their retention in a MBR, we considered two types of $\mathrm{SiO}_{2} \mathrm{NPs}$ based on size range, assessed their retention by comparison of activated sludge biomass between a control and an experimental group and confirmed their retention in a series of batch filtration tests.

Unlike a CAS, an MBR is challenged by membrane fouling [9], which can be more seriously challenged with colloidal particles such as $\mathrm{SiO}_{2} \mathrm{NPs}$ present in the wastewater [11]. In a microfiltration process alone, colloidal particles can foul the membrane by their accumulation on the membrane surface resulting in the formation of a so-called cake layer and/or by plugging the membrane pores [12]. The extent of these two membrane fouling events is also influenced by the size of the particles relative to the membrane pores [13]. Similarly, in an MBR that integrates microfiltration, colloidal particles in the range of $10 \mathrm{~nm}$ to $100 \mathrm{~nm}$ are responsible for a major part of membrane fouling [14]. Thus, if $\mathrm{SiO}_{2}$ NPs are present in wastewater entering an MBR, membrane fouling will be aggravated possibly due to interaction effect of $\mathrm{SiO}_{2} \mathrm{NPs}$ themselves and the assumed colloidal fraction of activated sludge. To investigate this, we monitored online the changes in the TMP of the MBRs from the same continuous lab-scale MBR experiments. We also performed a series of batch dead-end filtration tests to further investigate its effect on permeate flux and total resistance. This paper reports on our experimental investigation of the effects of $\mathrm{SiO}_{2} \mathrm{NPs}$ on an MBR. It describes the retention of $\mathrm{SiO}_{2} \mathrm{NPs}$ in an MBR and its implications for process performance and membrane fouling.

\section{Materials and Methods}

\subsection{Materials}

$\mathrm{SiO}_{2} \mathrm{NPs}$ were purchased from Nissan Chemical Industries (Tokyo, Japan). Two types of $\mathrm{SiO}_{2}$ NPs according to size were used, 10-15 nm (Snowtex ${ }^{\circledR}$ ST-30) and 70-100 nm (Snowtex ${ }^{\circledR}$ ST-ZL). Their hydrodynamic size in synthetic wastewater were $28 \mathrm{~nm}$ for Snowtex ${ }^{\circledR}$ ST-30 and $144 \mathrm{~nm}$ for Snowtex ${ }^{\circledR}$ ST-ZL based on our evaluation by using DLS (PSS Nicomp, Santa Barbara, CA, USA) following the manufacturer's instructions.

Three lab-scale MBRs, which were made of acryl plastic (polymethylmethacrylate), were used. Installed in each MBR setup was a $0.1 \mathrm{~m}^{2}$, flat sheet chlorinated-polyvinyl chloride (C-PVC) membrane module $(240 \mathrm{~mm} \times 340 \mathrm{~mm} \times 7.5 \mathrm{~mm})$ with a nominal pore size of $0.25 \mu \mathrm{m}$ (GS Yuasa, Kyoto, Japan). Each MBR setup was connected to an air pump with continuous fine bubble diffused aeration that was controlled at $5 \mathrm{~L} / \mathrm{min}$ by using an airflow meter (Dwyer, Michigan, IN, USA). The air diffuser was directly installed $5 \mathrm{~mm}$ beneath the membrane module. The activated sludge inoculum was obtained from an aerobic basin of a domestic wastewater treatment plant (Janghanpyeong, Seoul, South Korea).

The influent was a synthetic wastewater [15], whose composition includes $300 \mathrm{mg} / \mathrm{L}$ glucose $\left(\mathrm{C}_{6} \mathrm{H}_{12} \mathrm{O}_{6}\right), 260 \mathrm{mg} / \mathrm{L}$ ammonium sulfate $\left[\left(\mathrm{NH}_{4}\right)_{2} \mathrm{SO}_{4}\right], 8.5 \mathrm{mg} / \mathrm{L}$ potassium dihydrogen phosphate $\left(\mathrm{KH}_{2} \mathrm{PO}_{4}\right), 2.2 \mathrm{mg} / \mathrm{L}$ dipotassium hydrogen phosphate $\left(\mathrm{K}_{2} \mathrm{HPO}_{4}\right), 4.5 \mathrm{mg} / \mathrm{L}$ disodium hydrogen phosphate dodecahydrate $\left(\mathrm{Na}_{2} \mathrm{HPO}_{4} \cdot 12 \mathrm{H}_{2} \mathrm{O}\right), 9.4 \mathrm{mg} / \mathrm{L}$ manganese sulfate monohydrate $\left(\mathrm{MnSO}_{4} \cdot \mathrm{H}_{2} \mathrm{O}\right), 0.25 \mathrm{mg} / \mathrm{L}$ ferric chloride hexahydrate $\left(\mathrm{FeCl}_{3} \cdot 6 \mathrm{H}_{2} \mathrm{O}\right), 23.3 \mathrm{mg} / \mathrm{L}$ calcium chloride $\left(\mathrm{CaCl}_{2}\right), 22.5 \mathrm{mg} / \mathrm{L}$ magnesium sulfate heptahydrate $\left(\mathrm{MgSO}_{4} \cdot 7 \mathrm{H}_{2} \mathrm{O}\right)$ and $670 \mathrm{mg} / \mathrm{L}$ sodium bicarbonate $\left(\mathrm{NaHCO}_{3}\right)$ (Daejung Chemical \& Metal Co., Ltd., Shiheung, South Korea). 


\subsection{Continuous Lab-Scale MBR Experiments}

\subsubsection{Operating Conditions}

Three lab-scale submerged MBRs (Figure 1) were set up, each having an effective reactor volume $(V)$ of $6 \mathrm{~L}$. One MBR setup served as the control setup, i.e., $\mathrm{SiO}_{2} \mathrm{NPs}$ were not added to the influent. The two other MBR setups served as the experimental setups, i.e., $\mathrm{SiO}_{2} \mathrm{NPs}$ were added to the influent. All the MBR setups were operated under the same conditions as follows: $6 \mathrm{~h}$ hydraulic retention time (HRT), $20 \mathrm{~d}$ solids retention time (SRT) and $10 \mathrm{~L} /\left(\mathrm{m}^{2} \cdot \mathrm{h}^{-1}\right)$ influent/effluent flux. The average initial value of MLSS concentration of the three MBR setups was $4.2 \mathrm{~g}$ MLSS/L \pm 0.46 . The desired SRT was maintained by daily withdrawing $300 \mathrm{~mL}$ of activated sludge.

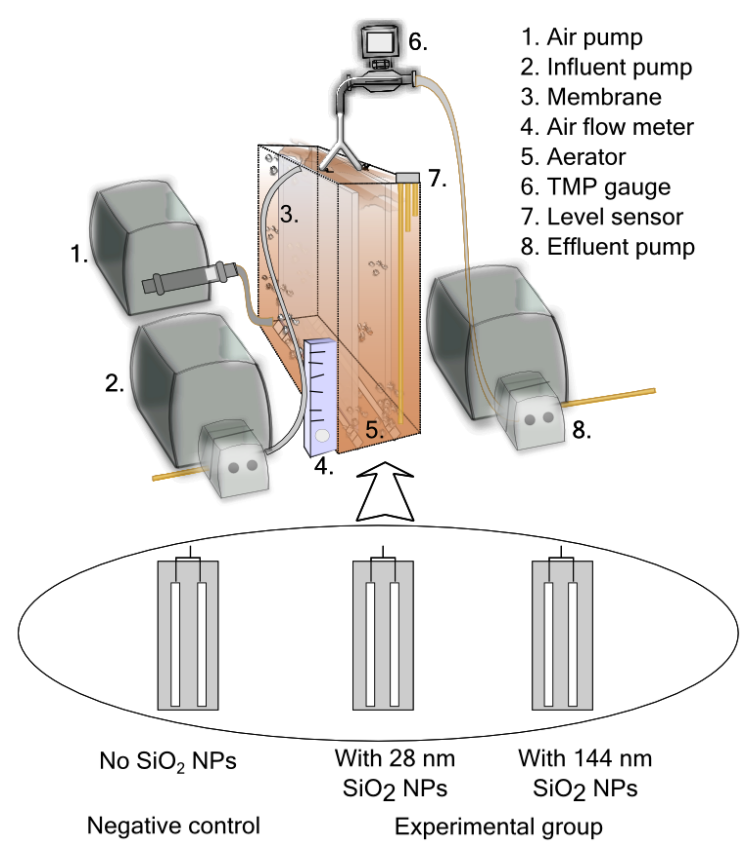

Figure 1. Schematic of the lab-scale membrane bioreactor (MBR) used in the continuous experiment.

When the removal of COD and $\mathrm{NH}_{3}-\mathrm{N}$ in all MBR setups had become stable (the values did not

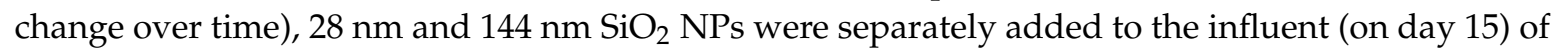
each experimental MBR setup at a final concentration of $100 \mathrm{mg} / \mathrm{L}\left(\mathrm{SiO}_{2}, 0.01 \mathrm{wt}\right.$ \%).

\subsubsection{Characterization of Activated Sludge}

The $\mathrm{pH}(7 \pm 1)$, dissolved oxygen (DO) $(7 \pm 1 \mathrm{mg} \mathrm{O} / \mathrm{L})$ and temperature $\left(22 \pm 1^{\circ} \mathrm{C}\right)$ of activated sludge were measured by using Thermo ${ }^{\circ}$ probes (Thermo Fisher Scientific Inc., Waltham, MA, USA). Their values did not differ significantly between the control and the two experimental MBR setups $[\mathrm{F}(2,21)=0.53, p>0.05]$. The MLSS and mixed liquor volatile suspended solids (MLVSS) were measured based on the Standard Methods [16]. Statistical significance of the difference between group means of data sets was determined by using one-way analysis of variance (ANOVA) and independent $t$-test (Origin Pro 8, OriginLab Corporation, Northampton, MA, USA). The same statistical analysis was done, where necessary, throughout the study.

\subsubsection{Activated Sludge Respiration Inhibition Test}

The oxygen uptake rate (OUR) was measured by using DO probes connected to a portable stand-alone data collection and analysis device (LabNavigator ${ }^{\mathrm{TM}}$, Forston Labs, Fort Collins, CO, USA). The samples were prepared as follows: $250 \mathrm{~mL}$ of the $300 \mathrm{~mL}$ waste sludge from each MBR setup 
was centrifuged at $4000 \mathrm{rpm}$ and $4{ }^{\circ} \mathrm{C}$ for $15 \mathrm{~min}$. The supernatant was discarded, the pellet was reconstituted with tap water and finally diluted to a final concentration of $3 \mathrm{~g}$ MLSS/L. From each dilution, $250 \mathrm{~mL}$ was obtained, mixed with $16 \mathrm{~mL}$ of Organization for Economic Cooperation and Development (OECD) 209 medium [17] and filled with tap water up to $500 \mathrm{~mL}$.

The mixture containing activated sludge taken from the control MBR setup was designated as the control $\left(R_{T B}\right)$ mixture. The remaining two mixtures with activated sludge taken from the two experimental MBR setups were the test mixtures $\left(R_{T}\right)$. In addition, $500 \mathrm{~mL}$ of the following abiotic control $\left(R_{T A}\right)$ mixtures were also tested: OECD 209 medium, $100 \mathrm{mg} / \mathrm{L}$ of $28 \mathrm{~nm} \mathrm{SiO} 2 \mathrm{NPs}$ and $144 \mathrm{~nm} \mathrm{SiO}{ }_{2}$ NPs. The procedures were based on the OECD 209 test guidelines [17] and the inhibition of total respiration $\left(I_{T}\right)$ was calculated using the equation:

$$
I_{T}=\left[1-\frac{R_{T}-R_{T A}}{R_{T B}}\right] \times 100 \% .
$$

\subsubsection{Performance Evaluation}

The concentrations of $\mathrm{COD}, \mathrm{NH}_{3}-\mathrm{N}$, total nitrogen (TN) and total phosphorus (TP) of both influent and effluent were measured three times a week by using water quality test kits (C-MAC Co., Ltd., Daejeon, Korea). The removal efficiency $(R)$ was calculated using the equation:

$$
R=\frac{C_{i}-C_{e}}{C_{i}} \times 100 \%
$$

where $C_{i}$ and $C_{e}$ are concentrations of each parameter in the influent and effluent, respectively. All water quality measurements were performed using an Optizen UV-VIS spectrophotometer with pre-programmed water analysis methods (Mecasys Co., Ltd., Daejeon, Korea).

\subsubsection{Transmembrane Pressure Monitoring}

A pressure transmitter was installed in each MBR setup for on-line monitoring of the changes in the TMP. It converts the pressure, which is detected from the elastic deformation of the silicon diaphragm of the integrated sensor chip, into an electrical signal in the presence of an auxiliary electrical supply (Keller-Druck, Winterthur, Switzerland). The pressure transmitter was connected to a computer for continuous data collection through a LabVIEW program (National Instruments, Austin, TX, USA). The TMP profile of each MBR setup was compared based on the absolute value of the slope of the linear portion of TMP versus time plot, at select points in time, i.e., when the TMP of the two experimental MBRs increased relative to the control MBR.

\subsection{Batch Experiments}

\subsubsection{Influence of $\mathrm{SiO}_{2} \mathrm{NPs}$ on MLSS Measurement}

To evaluate the potential contribution of $\mathrm{SiO}_{2}$ NPs to the increase in MLSS values of activated sludge (assuming that or if some of them remained in activated sludge), $50 \mathrm{mg} / \mathrm{L}, 100 \mathrm{mg} / \mathrm{L}, 250 \mathrm{mg} / \mathrm{L}$, $500 \mathrm{mg} / \mathrm{L}$ and $1000 \mathrm{mg} / \mathrm{L}$ each of $28 \mathrm{~nm}$ and $144 \mathrm{~nm} \mathrm{SiO}{ }_{2}$ NPs were subject to the same MLSS measurement as described on Section 2.2.2.

\subsection{2. $\mathrm{SiO}_{2} \mathrm{NPs}$ Settling Experiments and Dead-End Filtration Tests}

A total of $200 \mathrm{~mL}$ each of $28 \mathrm{~nm} \mathrm{SiO} \mathrm{NPs}_{2}(1000 \mathrm{mg} / \mathrm{L}), 144 \mathrm{~nm} \mathrm{SiO} \mathrm{NPs}(1000 \mathrm{mg} / \mathrm{L})$ and activated sludge ( $3 \mathrm{~g}$ MLSS/L) was prepared in the same but fresh synthetic wastewater. This group of samples served as controls. The experimental group was two mixtures consisting of each $\mathrm{SiO}_{2} \mathrm{NP}$ plus activated sludge. The final concentrations of $\mathrm{SiO}_{2} \mathrm{NPs}$ and activated sludge in the two mixtures were the same as those in the control group. 
A series of settling experiments were conducted to investigate the colloidal stability of $\mathrm{SiO}_{2} \mathrm{NPs}_{\text {. }}$ The experimental and control groups were mixed by continuous magnetic stirring at $125 \mathrm{rpm}$ (Daihan Scientific, Seoul, South Korea) for $30 \mathrm{~min}$ followed by gravitational settling for $3 \mathrm{~h}$. DLS analysis of the decantate from each sample was done to determine the hydrodynamic size of the dispersed particles present as described in Section 2.1. A batch dead-end filtration test of each samples from the control group (except activated sludge) and experimental group was conducted at $5 \mathrm{kPa}$, and DLS analysis was done to confirm the presence of $\mathrm{SiO}_{2} \mathrm{NPs}$ in the permeate.

A series of batch dead-end filtration tests were also conducted as described elsewhere [18-20], but the applied pressure was increased in a step-wise fashion during each run of batch dead-end filtration test. A detailed and determinative investigation of membrane fouling was unnecessary since we only aimed at briefly comparing the fouling trend observed during the continuous MBR experiments to that during the batch dead-end filtration; thus only for relative comparison. The total resistance $\left(R_{T}\right)$ was determined from each constant pressure data using the expression:

$$
J=\frac{\Delta P}{\mu R_{T}}
$$

The effect of $\mathrm{SiO}_{2}$ NPs on activated sludge microfiltration was investigated over a range of TMP $(\Delta P)$, from $5 \mathrm{kPa}$ to $35 \mathrm{kPa}$ at a $5-\mathrm{kPa}$ interval. We used a $180-\mathrm{mL}$ unstirred cell unit (Amicon 8200, Amicon $^{\mathrm{TM}}$, Danvers, MA, USA) and a $28.7 \mathrm{~cm}^{2}(A)$ C-PVC membrane that we cut from one whole sheet of the membrane. A new membrane was used in every batch dead-end filtration test and the permeate flux of deionized water $\left(J_{C W}\right)$ through the membrane at a given pressure was measured [21]. The values of permeate flux $(J)$ obtained from all of samples were normalized by their respective $J_{C W}$ values. The filtrate viscosity $(\mu)$ was measured by using a DV-II+Pro viscometer (Brookfield AMETEK, Inc., Middleboro, MA, USA) following the manufacturer's instructions.

\section{Results and Discussion}

\subsection{Retention of $\mathrm{SiO}_{2} \mathrm{NPS}$ in $\mathrm{MBR}$}

The evolution of MLSS following the addition of $\mathrm{SiO}_{2} \mathrm{NPs}$ in the two experimental MBR setups (Figure 2a) indicates retention of $\mathrm{SiO}_{2} \mathrm{NPs}$ in the mixed liquor. Unlike that in the control MBR setup, the MLSS concentration in the experimental MBR setups was increased by $0.08 \mathrm{~g}$ MLSS/L/d (with $28 \mathrm{~nm} \mathrm{SiO} 2 \mathrm{NPs}$ ) and $0.14 \mathrm{~g}$ MLSS/L/d (with $144 \mathrm{~nm} \mathrm{SiO} 2 \mathrm{NPs}$ ). MLVSS measurements in both the control MBR and experimental MBR setups, which did not differ significantly from each other $(\mathrm{F}(2,21)=3, p>0.05)$, confirm that the increasing MLSS concentration is non-biomass-related and is due to the accumulation of $\mathrm{SiO}_{2} \mathrm{NPs}$. Subsequent batch experiments with pure $\mathrm{SiO}_{2} \mathrm{NPs}_{\mathrm{S}}$ further confirm the contribution of $\mathrm{SiO}_{2}$ NPs to MLSS measurement due to their accumulation; $1000 \mathrm{mg} / \mathrm{L}$ $\mathrm{SiO}_{2} \mathrm{NPs}$ contributed as much as $0.3 \mathrm{~g} / \mathrm{L}$ and $0.7 \mathrm{~g} / \mathrm{L}$ for $28 \mathrm{~nm}$ and $144 \mathrm{~nm} \mathrm{SiO} \mathrm{NPs}_{2}$, respectively (Figure 2b).

At the end of the experiment, the final MLSS concentration in the experimental MBR setups relative to the control MBR setup (4.2 g MLSS/L) increased by $28 \%$ (with $28 \mathrm{~nm} \mathrm{SiO}_{2} \mathrm{NPs}$ ) and $64 \%$ (with $144 \mathrm{~nm} \mathrm{SiO}{ }_{2} \mathrm{NPs}$ ). Converting these percentage increases in MLSS concentration to wt. $\% \mathrm{SiO}_{2}$ NPs, approximately 0.12 wt. \% of $28 \mathrm{~nm} \mathrm{SiO} 2 \mathrm{NPs}$ and 0.27 wt. \% of $144 \mathrm{~nm} \mathrm{SiO}_{2} \mathrm{NPs}$ were present in

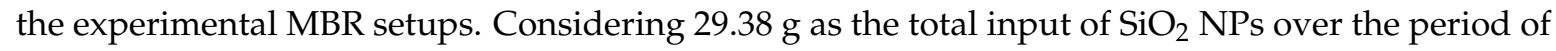
15 days of operation $\left(19.584 \mathrm{~L} / \mathrm{d} \times 15 \mathrm{~d} \times 100 \mathrm{mg} / \mathrm{L} \mathrm{SiO}_{2} \mathrm{NPs}\right)$, the estimated retention of $28 \mathrm{~nm} \mathrm{SiO} 2$ NPs and $144 \mathrm{~nm} \mathrm{SiO} 2$ NPs in the MLSS of MBR was $4 \%$ and $9 \%$, respectively.

The results demonstrate that some of the $\mathrm{SiO}_{2} \mathrm{NPs}$ accumulate in the mixed liquor despite their size being smaller than the membrane pore size, thus confirming actual exposure of activated sludge to $\mathrm{SiO}_{2} \mathrm{NPs}$. This is particularly important to subsequently evaluating the potential outcomes of the exposure of activated sludge to $\mathrm{SiO}_{2} \mathrm{NPs}$ in an MBR. 


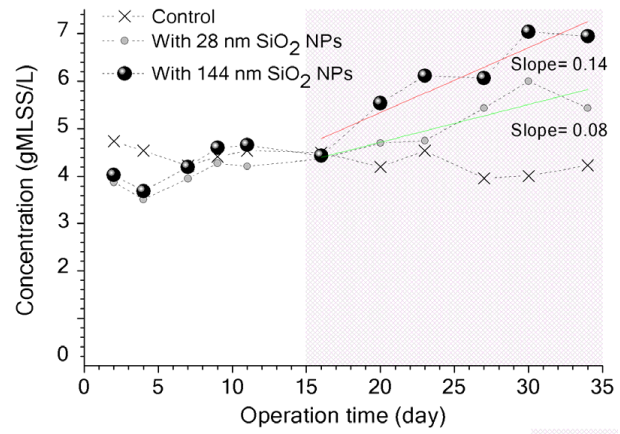

(a)

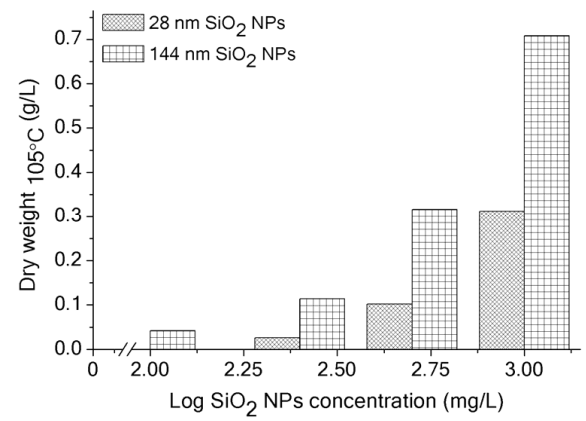

(b)

Figure 2. Effect of $\mathrm{SiO}_{2}$ NPs on the evolution of MLSS during (a) a continuous experiment in a membrane bioreactor (MBR) and (b) batch experiment with pure $\mathrm{SiO}_{2} \mathrm{NPs}$. The shaded area indicates exposure to $\mathrm{SiO}_{2}$ NPs.

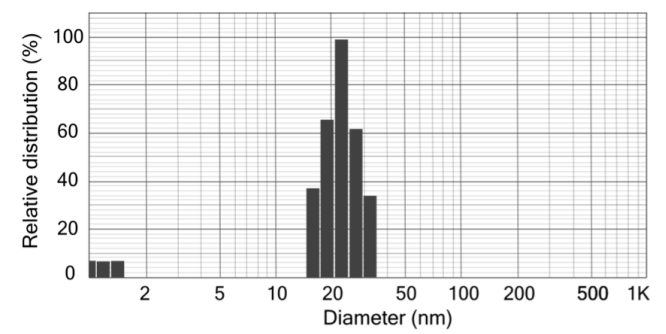

(a)

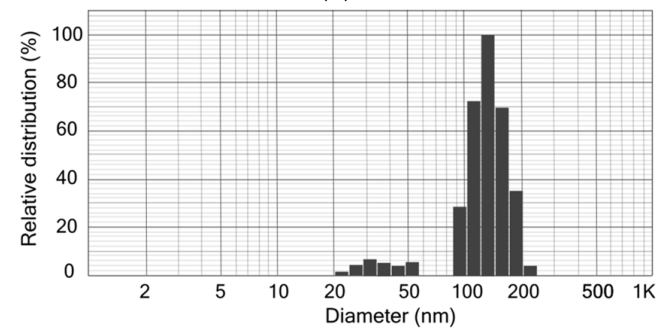

(c)

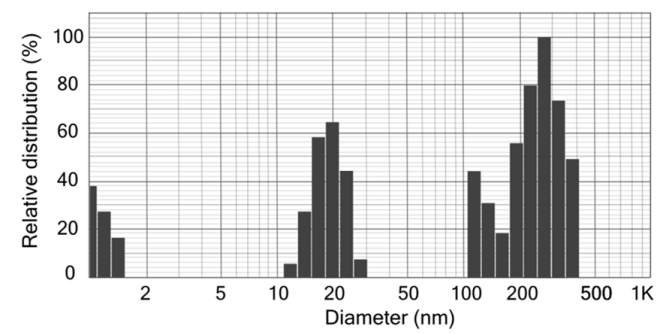

(b)

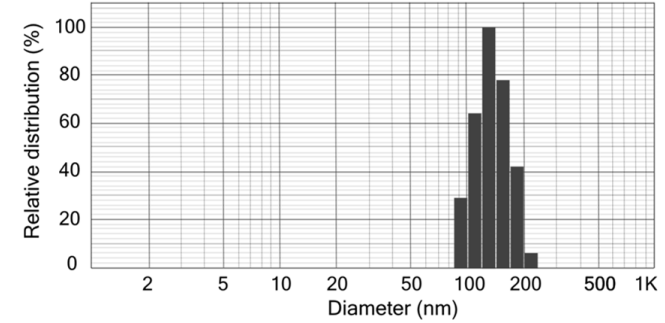

(d)

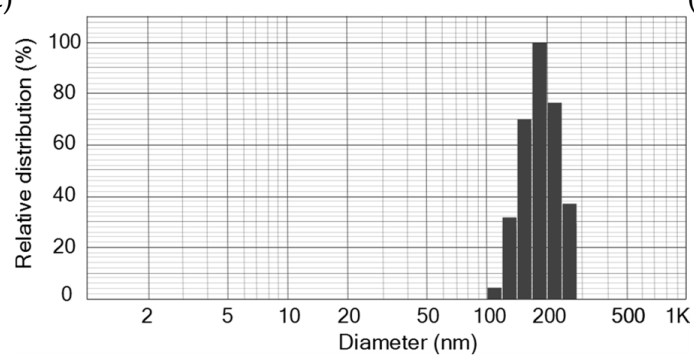

(e)

Figure 3. Particle size distribution of the decantate from batch settling experiments involving (a) $28 \mathrm{~nm} \mathrm{SiO} \mathrm{NPs}_{2}$ (b) $28 \mathrm{~nm} \mathrm{SiO} \mathrm{NPs}_{2}$ activated sludge; (c) $144 \mathrm{~nm} \mathrm{SiO} \mathrm{NPs}_{2}$ (d) $144 \mathrm{~nm} \mathrm{SiO}$ NPs + activated sludge and (e) activated sludge only.

With the substantial stability of $\mathrm{SiO}_{2}$ NPs due to their low point of zero charge in wastewater $(\mathrm{pH}<3.5)[1]$, some are most likely retained in the mixed liquor. For instance, in the secondary treatment of a CAS that involves deliberate settling of activated sludge, poor aggregation/sedimentation of $\mathrm{SiO}_{2} \mathrm{NPs}$ was observed [2] and for that same reason may hold true in activated sludge of an MBR. We demonstrated this in a batch settling experiment followed by DLS analysis of the decantate, where particles with nearly $28 \mathrm{~nm}$ and $144 \mathrm{~nm}$ size distribution were detected, suggesting the retention of $\mathrm{SiO}_{2} \mathrm{NPs}$ in the dispersion medium (synthetic wastewater and/or activated 
sludge) (Figure 3a-d). Meanwhile, particles of approximately between $100 \mathrm{~nm}$ to $400 \mathrm{~nm}$ were also present in the sample containing a mixture of $28 \mathrm{~nm} \mathrm{SiO} \mathrm{NPs}_{2}$ and activated sludge (Figure 3b), suggesting that some colloidal particles from activated sludge remain dispersed along with $\mathrm{SiO}_{2} \mathrm{NPs}_{\text {. }}$ These colloidal particles from activated sludge, however, are apparently not detectable in the sample containing a mixture of $144 \mathrm{~nm} \mathrm{SiO} 2 \mathrm{NPs}$ and activated sludge (Figure 3d) for some unknown reasons. We suspect that they may be present but overshadowed by the dominant presence of $144 \mathrm{~nm} \mathrm{SiO} 2 \mathrm{NPs}$ in the sample.

In an MBR, the estimated values for the retention of $\mathrm{SiO}_{2} \mathrm{NPs}$ may be expected to be lower than those reported in a CAS (35\%) [2]. This is reasonable because of (1) the continuous aeration in an MBR that further keeps $\mathrm{SiO}_{2} \mathrm{NPs}$ dispersed in the mixed liquor, (2) the suction pressure that facilitates their discharge into the effluent stream and (3) the size of $\mathrm{SiO}_{2} \mathrm{NPs}$ being smaller relative to the membrane pore size that allows them to easily pass through the membrane. DLS analysis confirms

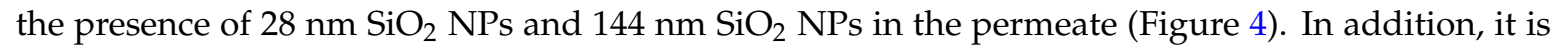
clear from DLS analysis that other than the $\mathrm{SiO}_{2} \mathrm{NPs}$, some colloidal particles from activated sludge of approximately less than $100 \mathrm{~nm}$ can also pass through the membrane (Figure $4 \mathrm{~b}$ ). The mean floc size of activated sludge used in the dead-end filtration tests was $7.5 \mathrm{um}(25 \%$ of distribution $<3.8 \mathrm{um}$, $50 \%$ of the distribution $<5.9 \mathrm{um}$ ). In an MBR system, the average size of activated sludge flocs can be as small as $5 \mathrm{um}$ and as large as $240 \mathrm{um}$ [9]. In the decantate (after allowing the activated sludge to settle), there remained particles with an average size of $191 \mathrm{~nm}$ (Figure 3e) while in the permeate (after filtration of activated sludge), $123 \mathrm{~nm}$ particles were detected (Figure 4e). Together, the results prove that some of the $\mathrm{SiO}_{2}$ NPs remain in the mixed liquor of an MBR, thus allowing potential interaction with activated sludge.

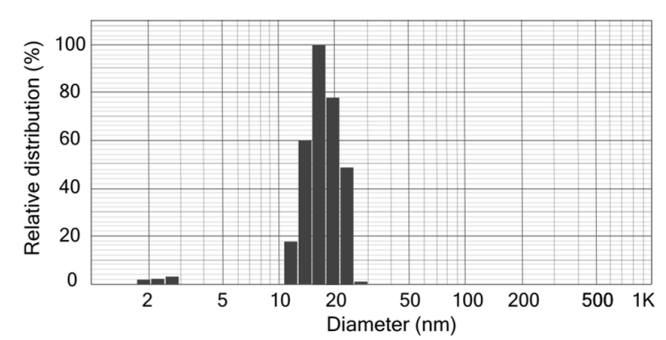

(a)

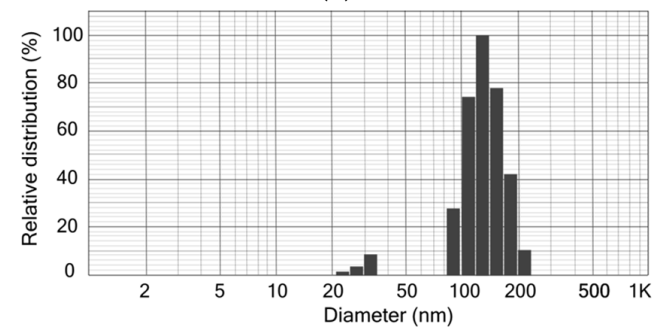

(c)

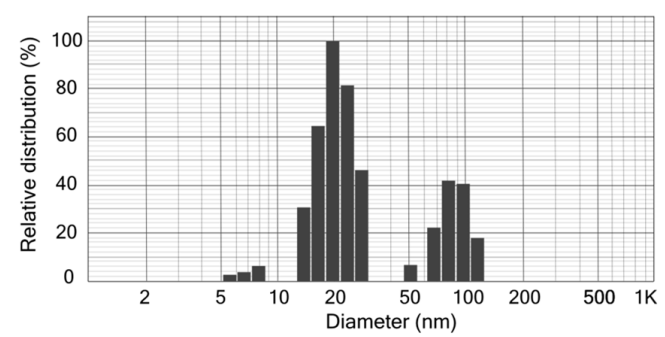

(b)

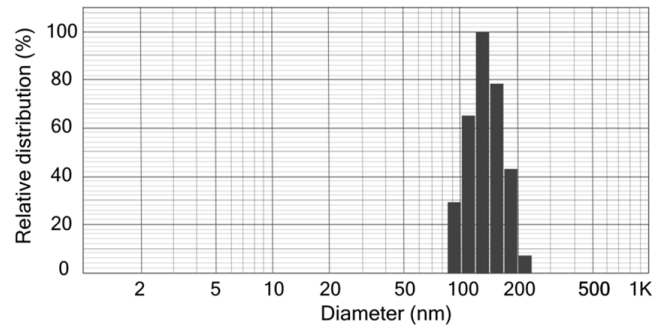

(d)

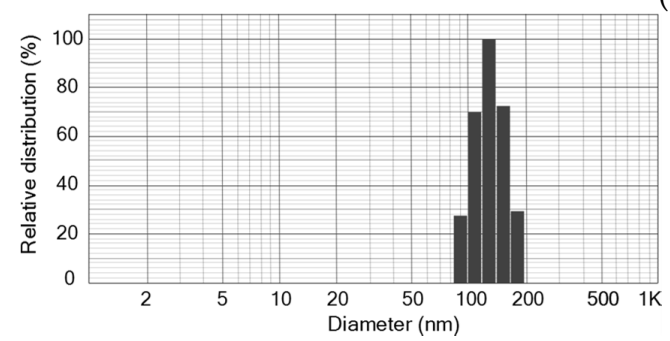

(e)

Figure 4. Particle size distribution of the permeate from dead-end filtration tests involving (a) $28 \mathrm{~nm}$ $\mathrm{SiO}_{2} \mathrm{NPs}$; (b) $28 \mathrm{~nm} \mathrm{SiO} 2 \mathrm{NPs}+$ activated sludge; (c) $144 \mathrm{~nm} \mathrm{SiO} \mathrm{NPs}_{2}$ (d) $144 \mathrm{~nm} \mathrm{SiO} \mathrm{NPs}_{2}+$ activated sludge and (e) activated sludge only. 


\subsection{Potential Biological Effect of $\mathrm{SiO}_{2} \mathrm{NPS}$ on Activated Sludge and MBR Performance}

That the total respiration decreased in the two experimental MBR setups indicates the potential biological effect of activated sludge exposure to $\mathrm{SiO}_{2} \mathrm{NPs}$. The maximum $I_{T}$ by $\mathrm{SiO}_{2} \mathrm{NPs}$ was as low as $5 \%$ (with $28 \mathrm{~nm} \mathrm{SiO} 2 \mathrm{NPs}$ ) and as high as $60 \%$ (with $144 \mathrm{~nm} \mathrm{SiO}_{2} \mathrm{NPs}$ ) (Figure 5).

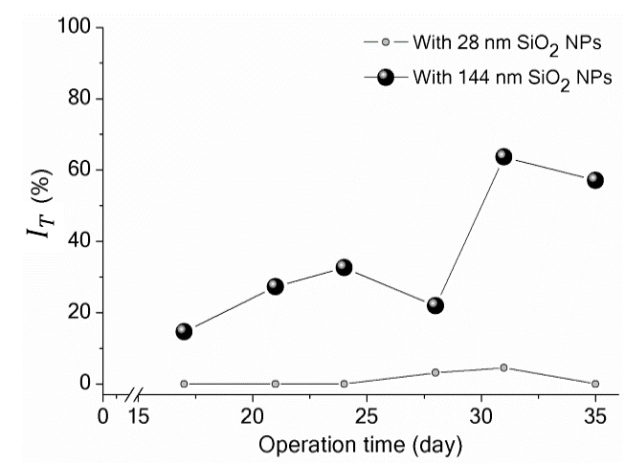

Figure 5. Inhibition of activated sludge total respiration $\left(I_{T}\right)$ in an $\mathrm{MBR}$ by $\mathrm{SiO}_{2} \mathrm{NPs}_{\text {. }}$

The lesser inhibitory effect of $28 \mathrm{~nm} \mathrm{SiO}{ }_{2} \mathrm{NPs}$ compared with that of $144 \mathrm{~nm} \mathrm{SiO} 2 \mathrm{NPs}$ may be due to the relatively lower retention of $28 \mathrm{~nm} \mathrm{SiO}_{2} \mathrm{NPs}$ in an MBR. Despite the same initial concentration of $\mathrm{SiO}_{2} \mathrm{NPs}$ in the influent of the two experimental MBR setups, the estimated amount of $\mathrm{SiO}_{2} \mathrm{NPs}$ in the mixed liquor actually differed (Figure 2) as did the extent of activated sludge exposure to $\mathrm{SiO}_{2} \mathrm{NPs}$.

The size-dependent toxicity of nanoparticles has been widely reported in literature, particularly in studies of nanoparticle toxicity in pure culture bacteria [22,23]. Previously, we have shown in batch experiments that smaller $\mathrm{SiO}_{2} \mathrm{NPs}(\sim 12 \mathrm{~nm}$ and $\sim 151 \mathrm{~nm})$ were more inhibitory than the larger $\mathrm{SiO}_{2}$ NPs (442 $\mathrm{nm}$ and $683 \mathrm{~nm}$ ) given that the concentration or dose did not change throughout the period of study [24]. The size-dependent toxicity of nanoparticles observed from these studies is most likely due to their greater surface area [25]. However, size-dependent toxicity was not observed in the present study. One reason is that despite the same initial $\mathrm{SiO}_{2} \mathrm{NPs}$ concentration, the exposure to $28 \mathrm{~nm} \mathrm{SiO}_{2}$ NPs and their respiration inhibitory effect are less than those of $144 \mathrm{~nm} \mathrm{SiO} \mathrm{NPs}_{2}$ because the smaller $\mathrm{SiO}_{2} \mathrm{NPs}$ can easily pass through the membrane, thus having lower retention in MBR activated sludge. Lower retention could mean lower exposure of MBR-activated sludge to $\mathrm{SiO}_{2} \mathrm{NPs}$.

Of the several possible mechanisms of nanoparticle-induced toxicity reviewed in the literature [26], oxidative stress, release of toxic cations and change in protein conformation mainly stand out [27]. However, there is no conclusive evidence for the mechanism of $\mathrm{SiO}_{2} \mathrm{NPs}$ inhibition of activated sludge total respiration although indirect evidence from fatty acid methyl ester (FAME) analysis of activated sludge suggests that $\mathrm{SiO}_{2} \mathrm{NPs}$ altered the composition of the microbial membrane lipids [24]. The potential biological effects of $\mathrm{SiO}_{2} \mathrm{NPs}$ on activated sludge warrants further investigations, especially because in nanotoxicity the key role of the interaction of nanoparticles (including $\mathrm{SiO}_{2} \mathrm{NPs}$ ) with proteins, which are also a component of activated sludge extracellular polymeric substances (EPS), has been recognized recently [28-30].

Similar to that observed in a CAS for yet unclear reasons, activated sludge exposure to $\mathrm{SiO}_{2}$ NPs [8] and their inhibitory effect on total respiration [24] were also not associated with low oxidation of COD and $\mathrm{NH}_{3}$. Over a period of 20 days after the exposure of activated $\mathrm{MBR}$ to $\mathrm{SiO}_{2} \mathrm{NPs}_{1} I_{\mathrm{T}}$ in the presence of $144 \mathrm{~nm} \mathrm{SiO}_{2} \mathrm{NPs}(M=37, S D=7)$ was higher than with $28 \mathrm{~nm} \mathrm{SiO}_{2} \mathrm{NPs}(M=8, S D=9)$, $t(10)=-6, p<0.05$. However, there was no statistically significant effect of exposure to both $\mathrm{SiO}_{2} \mathrm{NPs}$ on the removal of $\mathrm{COD}(\mathrm{F}(2,15)=0.08, p>0.05)$ and $\mathrm{NH}_{3}-\mathrm{N}(\mathrm{F}(2,13)=0.003, p>0.05)$. The removal of $\mathrm{TN}(\mathrm{F}(2,24)=0.32, p>0.05)$ and $\mathrm{TP}(\mathrm{F}(2,24)=1, p>0.05)$ also did not statistically differ between the control and the experimental setups. The overall performance of the control and experimental setups based on the removal of organic matter and nutrients are summarized in Table 1. Although it may be disregarded as a potential threat to the process performance of an MBR, the retention of $\mathrm{SiO}_{2} \mathrm{NPs}$ in the mixed liquor may pose a risk of membrane fouling [31,32]. 
Table 1. Summary of the performance of MBR with and without exposure to $\mathrm{SiO}_{2} \mathrm{NPs}$.

\begin{tabular}{|c|c|c|c|c|c|c|c|c|c|c|c|c|}
\hline \multirow{2}{*}{ Treatment } & \multicolumn{2}{|c|}{ COD (SD) mg/L } & \multirow[t]{2}{*}{ Removal \% } & \multicolumn{2}{|c|}{$\mathrm{NH}_{3}-\mathrm{N}$ (SD) mg/L } & \multirow[t]{2}{*}{ Removal \% } & \multicolumn{2}{|c|}{$\mathrm{TN}$ (SD) mg/L } & \multirow[t]{2}{*}{ Removal \% } & \multicolumn{2}{|c|}{$\mathrm{TP}$ (SD) $\mathrm{mg} / \mathrm{L}$} & \multirow[t]{2}{*}{ Removal \% } \\
\hline & Influent & Effluent & & Influent & Effluent & & Influent & Effluent & & Influent & Effluent & \\
\hline $\begin{array}{l}\text { MBR control } \\
\text { MBR with } 28 \mathrm{~nm} \mathrm{SiO} 2 \mathrm{NPs} \\
\text { MBR with } 144 \mathrm{~nm} \mathrm{SiO} 22 \mathrm{NPs}\end{array}$ & $\begin{array}{l}279(60) \\
282(54) \\
284(105)\end{array}$ & $\begin{array}{l}10(2) \\
10(2) \\
11(2)\end{array}$ & $\begin{array}{l}96 \\
96 \\
96\end{array}$ & $\begin{array}{l}39(9) \\
41(7) \\
40(9)\end{array}$ & $\begin{array}{l}<0.02 \\
<0.02 \\
<0.02\end{array}$ & $\begin{array}{l}99 \\
99 \\
99\end{array}$ & $\begin{array}{l}50(5) \\
48(3) \\
48(4)\end{array}$ & $\begin{array}{l}47(4) \\
44(3) \\
45(4)\end{array}$ & $\begin{array}{l}6 \\
8 \\
6\end{array}$ & $\begin{array}{l}11(2) \\
11(1) \\
11(1)\end{array}$ & $\begin{array}{l}9(1) \\
9(1) \\
9(1)\end{array}$ & $\begin{array}{l}18 \\
18 \\
18\end{array}$ \\
\hline
\end{tabular}




\subsection{Implications of $\mathrm{SiO}_{2} \mathrm{NPs}$ Retention for Membrane Fouling in an $\mathrm{MBR}$}

The slope of the linear portion of the TMP versus time plot of the two experimental MBR setups was relatively higher than that of the control MBR setup (Figure 6). This indicates an occurrence of membrane fouling that is apparently related to the relatively smaller $\mathrm{SiO}_{2} \mathrm{NPs}(28 \mathrm{~nm})$. The difference in the TMP values between the control and the experimental setups (with $28 \mathrm{~nm} \mathrm{SiO} \mathrm{NPs}_{2} \mathrm{NP}$ and $144 \mathrm{~nm}$ $\left.\mathrm{SiO}_{2} \mathrm{NPs}\right)$ was statistically significant $(F(2,78)=4, p=0.03)$. The TMP monitoring data agree with the observations from previous studies regarding the effects of colloidal particles, having relatively smaller size than the membrane pores, on microfiltration. We could infer that the most likely nature of the observed membrane fouling in the experimental MBR is pore plugging [13], although particle accumulation on the membrane surface [12] could also be responsible for this.

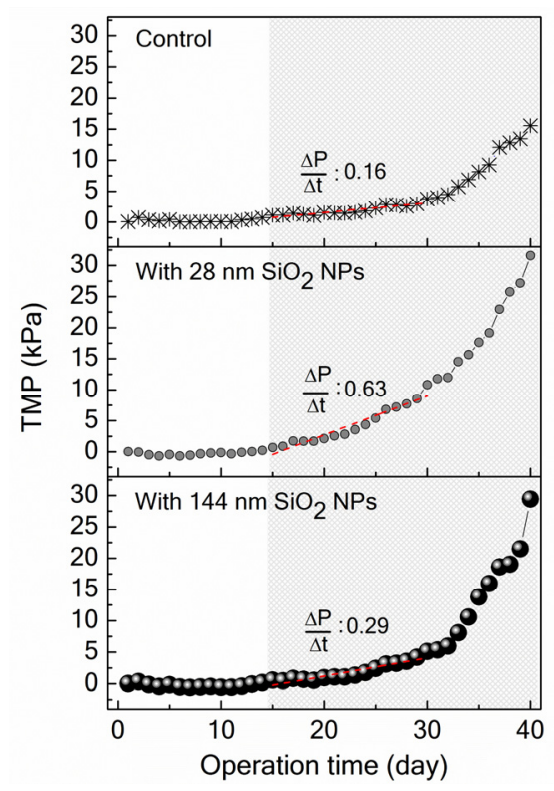

Figure 6. Effect of $\mathrm{SiO}_{2} \mathrm{NPs}$ on the evolution of transmembrane pressure (TMP) in an MBR. The shaded area indicates exposure to $\mathrm{SiO}_{2} \mathrm{NPs}$.

The $\mathrm{SiO}_{2} \mathrm{NPs}$, being in the "colloidal size range" between $1 \mathrm{~nm}$ and $1000 \mathrm{~nm}$ [33], are actually colloids [30]. Colloids are also implicated in membrane fouling, which we specifically refer to as colloidal fouling in the following discussion. Colloidal fouling is a phenomenon typical $[31,34,35]$ but not exclusive to microfiltration processes $[13,36,37]$. It is influenced by some factors including colloidal particle size, applied pressure and the interaction with other colloidal particles that may be present in activated sludge $[11,38,39]$.

However, the effect of each factor may differ depending on the extent of the other factor. We observed this during the comparative evaluation of permeate flux and total resistance of $\mathrm{SiO}_{2} \mathrm{NPs}$ only (28 nm and $144 \mathrm{~nm}$ ) and a mixture of each $\mathrm{SiO}_{2} \mathrm{NPs}$ and activated sludge at increasing TMP during the dead-end filtration tests.

All samples exhibit an initially decreasing permeate flux that levels off towards the end of the range of TMP tested. Alone (as a dispersion) or when mixed with activated sludge, the $28 \mathrm{~nm} \mathrm{SiO} 2$ NPs exhibited a higher permeate flux than did the $144 \mathrm{~nm} \mathrm{SiO}{ }_{2} \mathrm{NPs}$. However, in the experimental group, although the presence of both $\mathrm{SiO}_{2} \mathrm{NPs}$ in activated sludge decreases the permeate flux during the initial low-pressure stage, which can be as low as low as $30 \%(28 \mathrm{~nm} \mathrm{SiO} 2 \mathrm{NPs})$ and as high as $74 \%$ $\left(144 \mathrm{~nm} \mathrm{SiO}{ }_{2} \mathrm{NPs}\right)$, the permeate flux decline equalizes as TMP further increases from $10 \mathrm{kPa}$ to $35 \mathrm{kPa}$ (Figure 7). The results clearly show that $\mathrm{SiO}_{2} \mathrm{NPs}$ can reduce permeate flux during microfiltration of activated sludge. 


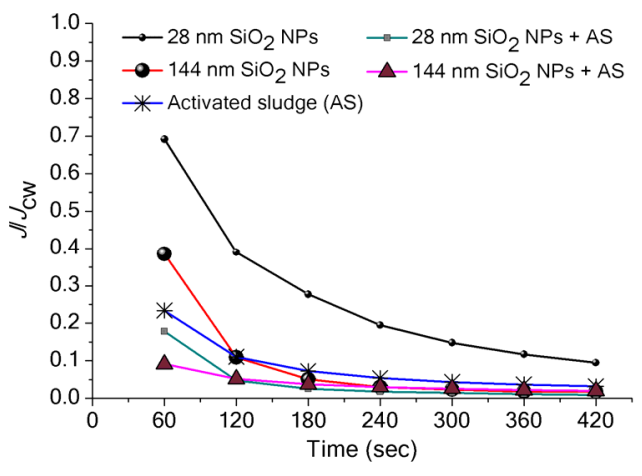

(a)

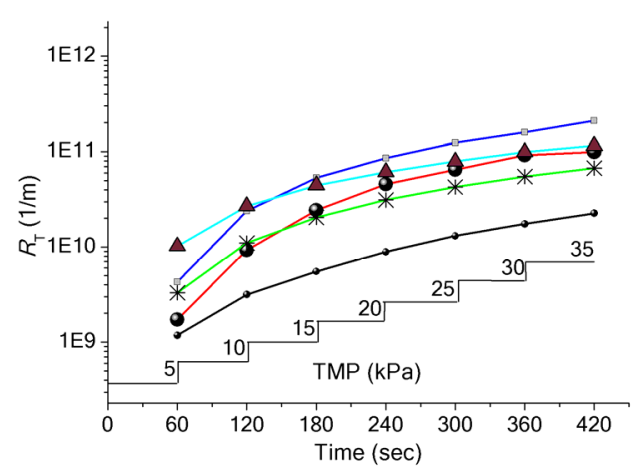

(b)

Figure 7. Membrane filtration characteristics in dead-end filtration of activated sludge with $\mathrm{SiO}_{2} \mathrm{NPs}$. (a) normalized permeate flux and (b) total resistance.

All samples also show an increasing total resistance over the range of TMP tested. The experimental group generally exhibits a higher total resistance, suggesting that the presence of $\mathrm{SiO}_{2}$ NPs can aggravate membrane fouling. Unlike the $\mathrm{SiO}_{2} \mathrm{NPs}$ alone, the $144 \mathrm{~nm} \mathrm{SiO} 2 \mathrm{NPs}$ when mixed with activated sludge, exhibit a higher total resistance only at the initial stage when the pressure

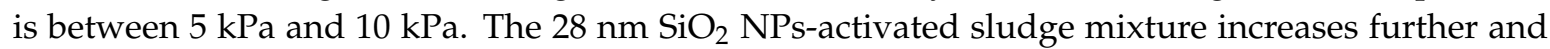
surpasses the $144 \mathrm{~nm} \mathrm{SiO}_{2} \mathrm{NPs}$ at much higher pressures (Figure 7).

In the experimental group, we suspect that the difference in the transport characteristics [36] of the two $\mathrm{SiO}_{2}$ is responsible for the difference in their values of permeate flux decline and total resistance at the initial low-pressure stage. Unlike the $28 \mathrm{~nm} \mathrm{SiO}_{2} \mathrm{NPs}$, the $144 \mathrm{~nm} \mathrm{SiO} \mathrm{NPs}_{2}$ are more easily retained in a cake layer along with other particles originating from activated sludge so they exert more hydraulic resistance and a corresponding permeate flux decline (Figure 7). However, as TMP further increases over time (Figure 6), $\mathrm{SiO}_{2} \mathrm{NPs}$ accumulate but the smaller particles form a more compact structure with less degree of porosity [11] as do the $28 \mathrm{~nm} \mathrm{SiO}_{2} \mathrm{NPs}$ along with other particles originating from activated sludge. This likely explains the observed further decreases in permeate flux and an increasing total resistance in the mixture of $28 \mathrm{~nm} \mathrm{SiO}{ }_{2} \mathrm{NPs}$ and activated sludge. Although our results clearly demonstrate that $\mathrm{SiO}_{2} \mathrm{NPs}$ aggravate membrane fouling in an MBR, it is possible that other factors that were not examined in this study, for example, the size of activated sludge flocs after exposure to $\mathrm{SiO}_{2} \mathrm{NPs}$, also contributed to membrane fouling. A recent study has shown that $\mathrm{SiO}_{2} \mathrm{NPs}$ at a final tested concentration of $100 \mathrm{mg} / \mathrm{L}$ improved flocculation ability of activated sludge after $24 \mathrm{~h}$ of exposure. The improved flocculation resulted from the decrease in the interaction barrier between activated sludge flocs as they were exposed to $\mathrm{SiO}_{2} \mathrm{NPs}$ [40]. The clear identification and differentiation of the mechanisms of membrane fouling observed in our study shall be considered for further investigations.

\section{Conclusions}

The retention of $\mathrm{SiO}_{2} \mathrm{NPs}$ in an MBR has no adverse effect on the removal of $\mathrm{COD}$ and $\mathrm{NH}_{3}-\mathrm{N}$ despite the observable inhibition of total respiration in activated sludge. However, it contributes to membrane fouling that results in TMP increases for a given flux, or conversely it can considerably reduce the permeate flux at a given TMP. More specifically, the presence of smaller $\mathrm{SiO}_{2} \mathrm{NPs}$ in activated sludge, contrary to that of the larger counterparts, eventually exerts higher total resistance as the TMP increases, although a substantial flux decline can already be observed at low TMP. As our results, which are similar to those in a CAS, show no detrimental effect of $\mathrm{SiO}_{2} \mathrm{NPs}$ on the overall performance of an MBR, we anticipate that future studies will further investigate the interaction of $\mathrm{SiO}_{2}$ NPs with activated sludge in an MBR, which is apparently where the challenge in fouling control lies. 
Acknowledgments: This research was supported by a grant from the Korean Ministry of Environment (MOE) as "The advancement of scientific research and technology development in environmental science program (2013001340004)".

Author Contributions: Mark Larracas Sibag and Jinwoo Cho conceived and designed the experiments; Mark Larracas Sibag and Soo Mi Lee performed the experiments; Mark Larracas Sibag and Soo Mi Lee analyzed the data; Jinwoo Cho and Hee Jun Kim contributed reagents/materials/analysis tools; Mark Larracas Sibag, Soo Mi Lee, Hee Jun Kim and Jinwoo Cho contributed to the writing of the manuscript.

Conflicts of Interest: The authors declare no conflict of interest.

\section{Abbreviations}

The following abbreviations are used in this manuscript:

$\begin{array}{ll}\text { CAS } & \text { Conventional activated sludge } \\ \text { COD } & \text { Chemical oxygen demand } \\ \text { DLS } & \text { Dynamic light scattering } \\ \text { TMP } & \text { Transmembrane pressure } \\ \text { MBR } & \text { Membrane bioreactor } \\ \text { C-PVC } & \text { Chlorinated polyvinyl chloride } \\ \text { DO } & \text { Dissolved oxygen } \\ \text { MLSS } & \text { Mixed liquor suspended solids } \\ \text { MLVSS } & \text { Mixed liquor volatile suspended solids } \\ \text { OUR } & \text { Oxygen uptake rate } \\ \text { OECD } & \text { Organization for economic cooperation and development } \\ \text { TN } & \text { Total nitrogen } \\ \text { TP } & \text { Total phosphorus }\end{array}$

\section{References}

1. Otero-González, L.; Barbero, I.; Field, J.A.; Shadman, F.; Sierra-Alvarez, R. Stability of alumina, ceria, and silica nanoparticles in municipal wastewater. Water Sci. Technol. 2014, 70, 1533-1539. [CrossRef] [PubMed]

2. Otero-González, L.; Field, J.A.; Calderon, I.A.; Aspinwall, C.A.; Shadman, F.; Zeng, C.; Sierra-Alvarez, R. Fate of fluorescent core-shell silica nanoparticles during simulated secondary wastewater treatment. Water Res. 2015, 77, 170-178.

3. Brar, S.K.; Verma, M.; Tyagi, R.D.; Surampalli, R.Y. Engineered nanoparticles in wastewater and wastewater sludge-Evidence and impacts. Waste Manage. 2010, 30, 504-520. [CrossRef] [PubMed]

4. Mohanty, A.; Wu, Y.; Cao, B. Impacts of engineered nanomaterials on microbial community structure and function in natural and engineered ecosystems. Applied Microbiol. Biot. 2014, 98, 8457-8468. [CrossRef] [PubMed]

5. Kiser, M.A.; Ryu, H.; Jang, H.; Hristovski, K.; Westerhoff, P. Biosorption of nanoparticles to heterotrophic wastewater biomass. Water Res. 2010, 44, 4105-4114. [CrossRef] [PubMed]

6. Park, H.J.; Kim, H.Y.; Cha, S.; Ahn, C.H.; Roh, J.; Park, S.; Kim, S.; Choi, K.; Yi, J.; Kim, Y.; Yoon, J. Removal characteristics of engineered nanoparticles by activated sludge. Chemosphere 2013, 92, 524-528. [CrossRef] [PubMed]

7. Rottman, J.; Shadman, F.; Sierra-Alvarez, R. Interactions of inorganic oxide nanoparticles with sewage biosolids. Water Sci. Technol. 2012, 66, 1821-1827. [CrossRef] [PubMed]

8. Zheng, X.; Su, Y.; Chen, Y. Acute and chronic responses of activated sludge viability and performance to silica nanoparticles. Environ. Sci. Technol. 2012, 46, 7182-7188. [CrossRef] [PubMed]

9. Judd, S. The MBR Book: Principles and Applications of Membrane Bioreactors for Water and Wastewater Treatment; Elsevier: Oxford, UK, 2010; pp. 174-176.

10. Auffan, M.; Rose, J.; Bottero, J.Y.; Lowry, G.V.; Jolivet, J.P.; Wiesner, M.R. Towards a definition of inorganic nanoparticles from an environmental, health and safety perspective. Nat. Nanotechnol. 2009, 4, 634-641. [CrossRef] [PubMed]

11. Wang, F.; Tarabara, V.V. Pore blocking mechanisms during early stages of membrane fouling by colloids. J. Colloid Interf. Sci. 2008, 328, 464-469. [CrossRef] [PubMed] 
12. Belfort, G.; Davis, R.H.; Zydney, A.L. The behavior of suspensions and macromolecular solutions in crossflow microfiltration. J. Membrane Sci. 1994, 96, 1-58. [CrossRef]

13. Zhu, X.; Elimelech, M. Colloidal fouling of reverse osmosis membranes: measurements and fouling mechanisms. Environ. Sci. Technol. 1997, 31, 3654-3662. [CrossRef]

14. Allen, P.T.; Stephenson, G.M. Inter-group understanding and size of organisation. Brit. J. Ind. Relat. 1983, 21, 312-329. [CrossRef]

15. Hur, J.; Shin, J.; Kang, M.; Cho, J. Tracking variations in fluorescent-dissolved organic matter in an aerobic submerged membrane bioreactor using excitation-emission matrix spectra combined with parallel factor analysis. Bioprocess. Biosyst. Eng. 2014, 37, 1487-1496. [CrossRef] [PubMed]

16. Rice, E.W.; Baird, R.B.; Eaton, A.D.; Clesceri, L.S. Standard Methods for the Examination of Water and Wastewater; American Public Health Association, American Water Works Association and Water Environment Federation: Washington, DC, USA, 2012.

17. Organization for Economic Co-operation and Development (OECD). OECD 209 Guideline for the Testing of Chemicals, Activated Sludge Respiration Inhibition Test; OECD: Paris, France, 1993.

18. Foley, G. Membrane Filtration: A Problem Solving Approach with MATLAB; Cambridge University Press: New York, NY, USA, 2013; pp. 16-45.

19. Cho, J.; Song, K.G.; Ahn, K.H. The activated sludge and microbial substances influences on membrane fouling in submerged membrane bioreactor: unstirred batch cell test. Desalination 2005, 183, 425-429. [CrossRef]

20. Ahmed, Z.; Cho, J.; Lim, B.R.; Song, K.G.; Ahn, K.H. Effects of sludge retention time on membrane fouling and microbial community structure in a membrane bioreactor. J. Membrane Sci. 2007, 287, 211-218. [CrossRef]

21. Munir, A. Dead end membrane filtration, laboratory feasibility studies in environmental engineering. Available online: http://www.egr.msu.edu/ hashsham/courses/ene806/docs/Membrane\%20Filtration. pdf (accessed on 27 June 2016).

22. Simon-Deckers, A.; Loo, S.; Mayne-L’hermite, M.; Herlin-Boime, N.; Menguy, N.; Reynaud, C.; Gouget, B.; Cariere, M. Size-, composition-and shape-dependent toxicological impact of metal oxide nanoparticles and carbon nanotubes toward bacteria. Environ. Sci. Technol. 2009, 43, 8423-8429. [CrossRef] [PubMed]

23. Hajipour, M.J.; Fromm, K.M.; Ashkarran, A.A.; de Aberasturi, D.J.; de Larramendi, I.R.; Rojo, T.; Serpooshan, V.; Parak, W.J.; Mahmoudi, M. Antibacterial properties of nanoparticles. Trends Biotechnol. 2010, 30, 499-511. [CrossRef] [PubMed]

24. Sibag, M.; Choi, B.G.; Suh, C.; Lee, K.H.; Lee, J.W.; Maeng, S.K.; Cho, J. Inhibition of total oxygen uptake by silica nanoparticles in activated sludge. J. Haz. Mat. 2015, 283, 841-846. [CrossRef] [PubMed]

25. Jiang, W.; Mashayekhi, H.; Xing, B. Bacterial toxicity comparison between nano-and micro-scaled oxide particles. Environ. Pollut. 2009, 157, 1619-1625. [CrossRef] [PubMed]

26. Manke, A.; Wang, L.; Rojanasakul, Y. Mechanisms of nanoparticle-induced oxidative stress and toxicity. BioMed Res. Int. 2013, 2013, 942916. [CrossRef] [PubMed]

27. Bottero, J.Y. Environmental risks of nanotechnology: A new challenge? In Nanosciences and Nanotechnology; Springer International Publishing: Cham, Switzerland, 2016; pp. 287-311.

28. Zanganeh, S.; Spitler, R.; Erfanzadeh, M.; Mahmoudi, M. Protein Corona: Opportunities and Challenges. Int. J. Biochem. Cell. Biol. 2016, 75, 143-147. [CrossRef] [PubMed]

29. Saptarshi, S.R.; Duschl, A.; Lopata, A.L. Interaction of nanoparticles with proteins: relation to bio-reactivity of the nanoparticle. J. Nanobiotechnol. 2013, 11, 26. [CrossRef] [PubMed]

30. Lynch, I.; Cedervall, T.; Lundqvist, M.; Cabaleiro-Lago, C.; Linse, S.; Dawson, K.A. The nanoparticle-protein complex as a biological entity; a complex fluids and surface science challenge for the 21st century. Adv. Colloid Interface Sci. 2012, 134, 167-174. [CrossRef] [PubMed]

31. Pan, J.R.; Huang, C.; Jiang, W.; Chen, C. Treatment of wastewater containing nano-scale silica particles by dead-end microfiltration: evaluation of pretreatment methods. Desalination 2005, 179, 31-40. [CrossRef]

32. Singh, G.; Song, L. Quantifying the effect of ionic strength on colloidal fouling potential in membrane filtration. J. Colloid Interface Sci. 2005, 28, 630-638. [CrossRef] [PubMed]

33. Kissa, E. Dispersions: Characterization, Testing, and Measurement; CRC Press: Boca Raton, FL, USA, 1999; Volume 84.

34. Trzaskus, K.W.; Zdeb, A.; de Vos, W.M.; Kemperman, A.; Nijmeijer, K. Fouling behavior during microfiltration of silica nanoparticles and polymeric stabilizers. J. Membrane Sci. 2016, 505, 205-215. [CrossRef] 
35. Guo, W.; Ngo, H.H.; Li, J. A mini-review on membrane fouling. Bioresour. Technol. 2012, 122, 27-34. [CrossRef] [PubMed]

36. Boo, C.; Lee, S.; Elimelech, M.; Meng, Z.; Hong, S. Colloidal fouling in forward osmosis: Role of reverse salt diffusion. J. Membrane Sci. 2012, 390, 277-284. [CrossRef]

37. Shirazi, S.; Lin, C.J.; Chen, D. Inorganic fouling of pressure-driven membrane processes-A critical review. Desalination 2010, 250, 236-248. [CrossRef]

38. Rosenberger, S.; Laabs, C.; Lesjean, B.; Gnirss, R.; Amy, G.; Jekel, M.; Schrotter, J.C. Impact of colloidal and soluble organic material on membrane performance in membrane bioreactors for municipal wastewater treatment. Water Res. 2006, 40, 710-720. [CrossRef] [PubMed]

39. Laabs, C.N.; Amy, G.L.; Jekel, M. Understanding the size and character of fouling-causing substances from effluent organic matter (EfOM) in low-pressure membrane filtration. Environ. Sci. Technol. 2006, 40, 4495-4499. [CrossRef] [PubMed]

40. Xu, J.; Li, X.Y. Investigation of the effect of nanoparticle exposure on the flocculability of activated sludge using particle image volecimetry in combination with the extended DLVO analysis. Colloids Surf. B Biointerfaces. 2016, 143, 382-389. [CrossRef] [PubMed]

(C) 2016 by the authors; licensee MDPI, Basel, Switzerland. This article is an open access article distributed under the terms and conditions of the Creative Commons Attribution (CC-BY) license (http://creativecommons.org/licenses/by/4.0/). 